\title{
Phytogenic feed additives in piglets challenged with Salmonella Typhimurium ${ }^{1}$
}

\section{Daniel Gonçalves Bruno², Simone Maria Massami Kitamura Martins ${ }^{2}$, Larissa José Parazzi², Esther Ramalho Afonso², Tácia Antunes Del Santo², Sergio de Mello Novita Teixeira ${ }^{3}$, Andrea Micke Moreno ${ }^{3}$, Aníbal de Sant'Anna Moretti ${ }^{2}$}

\author{
${ }^{1}$ Project funded by FAPESP. \\ ${ }^{2}$ Departamento de Nutrição e Produção Animal, FMVZ/USP. \\ ${ }^{3}$ Departamento de Medicina Veterinária Preventiva e Saúde Animal, FMVZ/USP.
}

\begin{abstract}
The effects of phytogenic feed additives on piglet performance and fecal score (FDD), as well as on lipid oxidation of pork meat were evaluated. One hundred and twenty crossbred weaned piglets were randomly assigned to six treatments according to a $2 \times 3$ factorial design with five replicates per treatment. Factors were: challenge with Salmonella Typhimurium at 35 days of age or no challenge, and three different additives (control (CTR), basal diet; phytogenic feed additives (PHY), basal diet plus 2000 ppm of phytogenic feed additives - Rosmarinus officinalis, Mentha piperita, Lippia sidoides and Porophyllum ruderale; and antimicrobial agent (ATB), basal diet plus $100 \mathrm{ppm}$ of tylosin, $2000 \mathrm{ppm}$ of zinc and colistin sulfate, $30 \mathrm{ppm}$ in the pre-starter basal diet, $10 \mathrm{ppm}$ in the starter basal diet I and II, and 5 ppm in growth and finishing basal diet). Body weight (BW) of the piglets of ATB was greater throughout the experimental period, without any differences detected between CTR and PHY. Nevertheless, from 96 to 106 days of age, the BW of the CTR group was greater than PHY. From 21 to 34 days of age, feed conversion of ATB was lower than CTR; however, PHY showed an intermediate result, which did not differ from either ATB or CTR. Challenged animals reduced feed intake from day 35 to 48 compared with unchallenged animals. Piglet performance and fecal score from 21 to 48 days of age were lower in piglets that received ATB compared with the other treatments. However, from 35 to 48 days of age, the FDD of PHY was lower than CTR. Lipid oxidation was not reduced in treated animals. Antimicrobial agent improved the growth performance of piglets until 63 days of age, and no difference was observed between the treatments from 64 to 131 days of age. Antimicrobial agent reduced FDD; the FDD of PHY was similar to that of ATB after 48 days. None of the treatments affected lipid oxidation of pork meat.
\end{abstract}

Key Words: diarrhea, growth promoter, lipid oxidation, performance, phytogenic compounds, swine

\section{Introduction}

The main action of antimicrobial agents used as growth promoters in pig production is to prevent digestive problems, improving feed use and, consequently, animal performance. However, the use of these growth promoters started to be questioned due to the possible reduction of the population of beneficial intestinal microorganisms, and the development of bacterial cross resistance (Mazel \& Davies, 1999).

The ban on antimicrobials by the European Union in 2006 has intensified the search for alternative substances that act as growth promoters (Zani et al., 1998), such as phytogenic additives, prebiotics, probiotics, organic acids and others (Alexopoulos et al., 2004).

Among these alternatives, phytogenic additives have demonstrated antimicrobial properties in vitro (Duarte et al., 2005) and in vivo by modulating the intestinal microbiota and favoring the preservation of beneficial bacteria (Namkung et al., 2004). Besides these actions, other properties have been reported. A few examples are the antioxidant action, which improves the oxidative stability of the meat (Botsoglou et al., 2004), and hepatoprotective, detoxifying (Debersac et al., 2001) and immunomodulatory actions (Spelman et al., 2006) and stimulation of enzyme secretion (Oetting, 2005), which interfere, therefore, with feed digestibility.

The phytogenic additives (Rosmarinus officinalis, Mentha piperita, Lippia sidoides and Porophyllum ruderale) analyzed in the present study have already been tested in pigs in the growth and finishing phases, and led to improved weight gain and feed conversion during the growth phase (Martins et al., 2005), but there is still little information on the influence of plant extracts on the performance of production animals (Botsoglou et al., 2004; Utiyama et al., 2006).

Based on these facts, the objective of the present study was to evaluate the effects of a phytogenic additive on the 
performance and incidence of diarrhea, as well as on lipid oxidation of pork meat, in pigs challenged with Salmonella Typhimurium during the starter, growth and finishing phases.

\section{Material and Methods}

The study was conducted at Laboratório de Pesquisa em Suínos da Faculdade de Medicina Veterinária e Zootecnia da Universidade de São Paulo (FMVZ/USP). The procedures and experimental use of the animals were approved by the Bioethics Committee of FMVZ/USP, protocol no. 1228/2007.

A total of 120 crossbred piglets, weaned at 21 days of age (mean weight $5.79 \pm 0.49 \mathrm{~kg}$ ) were obtained from a commercial pig breeding facility. Piglets were housed in Laboratório de Pesquisa em Suínos da FMVZ/USP, Pirassununga Campus.

Animals were randomly assigned to six treatments according to a $2 \times 3$ factorial design. The following factors were analyzed: challenge (challenged or unchallenged with inoculation of Salmonella Typhimurium) and feed additive (antimicrobial agent; phytogenic additive; and control, absence of promoter), in a total of 6 treatments. Experimental units were composed of enclosures set above ground in the nursery unit and pens with a channel water trough at the growth/finishing unit. Each unit had 4 pigs, with five replications per treatment.

The phytogenic additive was prepared with leaves, flowers and stalks of four medicinal plants collected in July 2007, in the city of Bauru, Sao Paulo state, Brazil. The different parts of these plants were dehydrated and ground, and contained the respective active ingredients: Mentha piperita, $43 \mathrm{~g}$, with $215 \mathrm{mg}$ of menthol and menthofuran; Rosmarinus officinallis, $43 \mathrm{~g}$, with $215 \mathrm{mg}$ of cineole, alpha-pinene, camphor and bitter diterpenes; Lippia sidoides, $86 \mathrm{~g}$, with $50 \mathrm{mg}$ of myrcene, citral, limonene, and carvone; and Porophyllum ruderale, $43 \mathrm{~g}$, with $200 \mathrm{mg}$ of quersitine, inulin, rutin, chlorogenic, caffeic and hydrocinnamic acid.

The basal diet formula, according to the NRC (1998), did not contain any antimicrobial agent or growth factor. Treatments used were: control - basal diet; phytogenic additives - basal diet with 2,000 ppm of phytogenic additive; and antimicrobial agent - basal diet with tylosin (100 ppm), zinc (2000 ppm - $\mathrm{ZnO}$ ) and colistine sulfate (30 ppm in the pre-starter phase, $10 \mathrm{ppm}$ in starter phase I and II; and $5 \mathrm{ppm}$ in growth and finishing phase; Tables 1 and 2).

Water and feed were supplied ad libitum and feed was offered according to the phase of the rearing cycle, described below: pre-starter phase, from 21 to 34 days of age; starter
Table 1 - Composition (in $\mathrm{kg}$ ) of the experimental diet offered during the starter phase

\begin{tabular}{|c|c|c|c|}
\hline \multirow{2}{*}{ Ingredients $(\mathrm{g} / \mathrm{kg})$} & \multicolumn{3}{|c|}{ Feed } \\
\hline & Pre-starter & Starter I & Starter II \\
\hline Soybean meal & 333.32 & 333.80 & 328.00 \\
\hline Cracker meal & 120.00 & 60.00 & - \\
\hline Ground corn & - & - & 598.00 \\
\hline Corn meal & 428.64 & 533.52 & - \\
\hline Milk whey & 40.00 & 10.00 & - \\
\hline Dicalcium phosphate & 16.00 & 15.00 & 18.50 \\
\hline Calcite limestone & - & 5.40 & 7.00 \\
\hline Lactose & 12.00 & 4.00 & - \\
\hline Sugar & 30.00 & 30.00 & 40.00 \\
\hline Sodium chloride & 3.20 & 2.60 & 6.00 \\
\hline L-lysine, 78\% & 2.80 & 1.40 & - \\
\hline DL-methionine, $99 \%$ & 3.60 & 1.00 & - \\
\hline Phytase & 0.12 & 0.06 & - \\
\hline Choline & 0.32 & 0.22 & - \\
\hline Flavoring agent & 8.00 & 1.00 & - \\
\hline Vitamin $\operatorname{mix}^{1}$ & 2.00 & 1.00 & 1.00 \\
\hline Mineral $\operatorname{mix}^{2}$ & - & 1.00 & 1.50 \\
\hline
\end{tabular}

1 Vitamin supplementation for every $1.0 \mathrm{~kg}$ of the product (Rovimix ${ }^{\circledR}$, DSM) selenium - $0.3 \mathrm{~g}$; vit. A - 10,000,000 IU; vit. $\mathrm{D}_{3}-2,000,000 \mathrm{IU}$; vit. E - $50 \mathrm{~g}$; vit. $\mathrm{K}_{3}-2 \mathrm{~g}$; vit. $\mathrm{B}_{1}-2 \mathrm{~g}$; vit. $\mathrm{B}_{2}-6 \mathrm{~g}$; vit. $\mathrm{B}_{6}-3$ g; vit. $\mathrm{B}_{12}-30 \mathrm{~g}$; niacin - $30 \mathrm{~g}$; pantothenic acid $-15 \mathrm{~g}$; folic acid $-3 \mathrm{~g}$; biotin $-0.2 \mathrm{~g}$.

${ }^{2}$ Mineral supplementation for every $1.0 \mathrm{~kg}$ of the product (Roligomix ${ }^{\circledR}, \mathrm{DSM}$ ):

iron - $100 \mathrm{~g}$; copper - $20 \mathrm{~g}$; zinc - $100 \mathrm{~g}$; manganese - $40 \mathrm{~g}$; iodine - $1.5 \mathrm{~g}$.

Table 2 - Composition (in $\mathrm{kg}$ ) of the experimental diet offered during the growth and finishing phases

\begin{tabular}{|c|c|c|}
\hline \multirow{2}{*}{ Ingredients $(\mathrm{g} / \mathrm{kg})$} & \multicolumn{2}{|c|}{ Feed } \\
\hline & Growth & Finishing \\
\hline Corn & 620.13 & 636.41 \\
\hline Rice meal & 87.09 & 117.84 \\
\hline Animal fat & 3.48 & 5.66 \\
\hline Soybean meal $45 \%$ & 236.44 & 189.01 \\
\hline Meat meal $42 \%$ & 18.72 & 12.25 \\
\hline Sodium chloride & 4.09 & 4.43 \\
\hline Sugar cane yeast (roll) & 8.71 & 9.43 \\
\hline Calcite limestone & 5.23 & 7.54 \\
\hline Mineral $\operatorname{mix}^{1}$ & 2.18 & 2.36 \\
\hline Vitamin $\operatorname{mix}^{2}$ & 4.35 & 4.01 \\
\hline DL-methionine, $99 \%$ & 0.87 & - \\
\hline L-lysine, $78 \%$ & 5.66 & 6.36 \\
\hline L-threonine, $98.5 \%$ & - & 1.18 \\
\hline Choline & 0.87 & 1.18 \\
\hline Multi-enzymatic complex & 2.18 & 2.36 \\
\hline \multicolumn{3}{|c|}{ 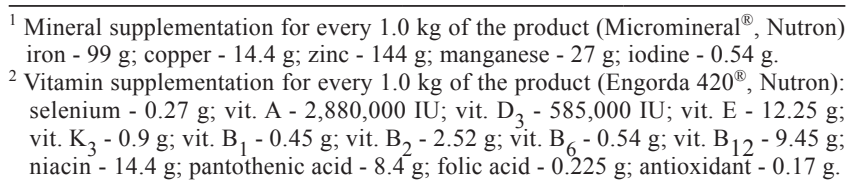 } \\
\hline
\end{tabular}

phase I, from 35 to 48 days of age; starter phase II, from 49 to 63 days of age; growth phase, from 64 to 105 days of age; and finishing phase, from 106 to 131 days of age.

Salmonella Typhimurium (LSS90/05) was isolated by Laboratório de Sanidade e Virologia Suína da FMVZ/USP. At 35 days of age, each piglet of the challenged group received $1 \mathrm{~mL}$ of a solution containing the bacterium at a concentration of $1 \times 10^{5} \mathrm{cfu} / \mathrm{mL}$, orally. Challenged piglets were housed in a separate room. 
Visual analysis of the feces was carried out every day, with scores ranging from 1 to 3 for each animal: $1=$ solid feces (normal); 2 = feces softer than normal (pasty); and $3=$ liquid feces (severe diarrhea). This evaluation was done by two adequately trained professionals working in separate rooms. After that, the frequency of days with diarrhea (FDD) was analyzed, which was the quotient between the sum of the number of days in which the animals had pasty and liquid feces and the number of days of analysis, in the following intervals: 21 to 34 days of age; 35 to 48 days of age and 49 to 63 days of age.

At the end of the study, 9 piglets in the unchallenged group (three of each treatment) were killed by bleeding with incision of the jugular vein, after stunning by electric shock (high voltage, low current). The analysis of lipid oxidation of the carcass was carried out according to the thiobarbituric acid reactive substance assay (TBARS; Vyncke et al., 1970) at Laboratório de Neurociência e Proteômica da FZEA/USP.
Longissimus dorsi fragments were collected between the fifth and sixth lumbar vertebrae (4 samples per animal). Samples were immediately wrapped in aluminum foil, identified and frozen in liquid nitrogen. They were kept in a freezer at $-80{ }^{\circ} \mathrm{C}$ until the moment of analysis.

The following performance variables were analyzed: body weight (BW, kg) at 21, 35, 49, 63, 96, 106 and 131 days of age; daily weight gain (DWG, g/day) (Table 3); daily feed intake (DFI, g/day); and feed conversion (FC) from 21 to $34 ; 35$ to $48 ; 49$ to $62 ; 63$ to $95 ; 96$ to 105 ; and 106 to 131 days of age.

In the statistical analysis, data on the frequency of diarrhea were transformed using the function $\mathrm{y}=\arcsin$ $\sqrt{(p / 100)}$ (Banzatto \& Kronka, 1989). All variables were analyzed by GLM for the analysis of variance, and means were compared by Tukey's test. All analyses were carried out on software SAS (Statistical Analysis System, version 6.12 ), at a $5 \%$ significance level.

Table 3 - Daily weight gain (g/day) in piglets receiving feed with addition of phytogenic additive, antimicrobial, or the control diet, kept in challenged or unchallenged rooms ${ }^{3}$

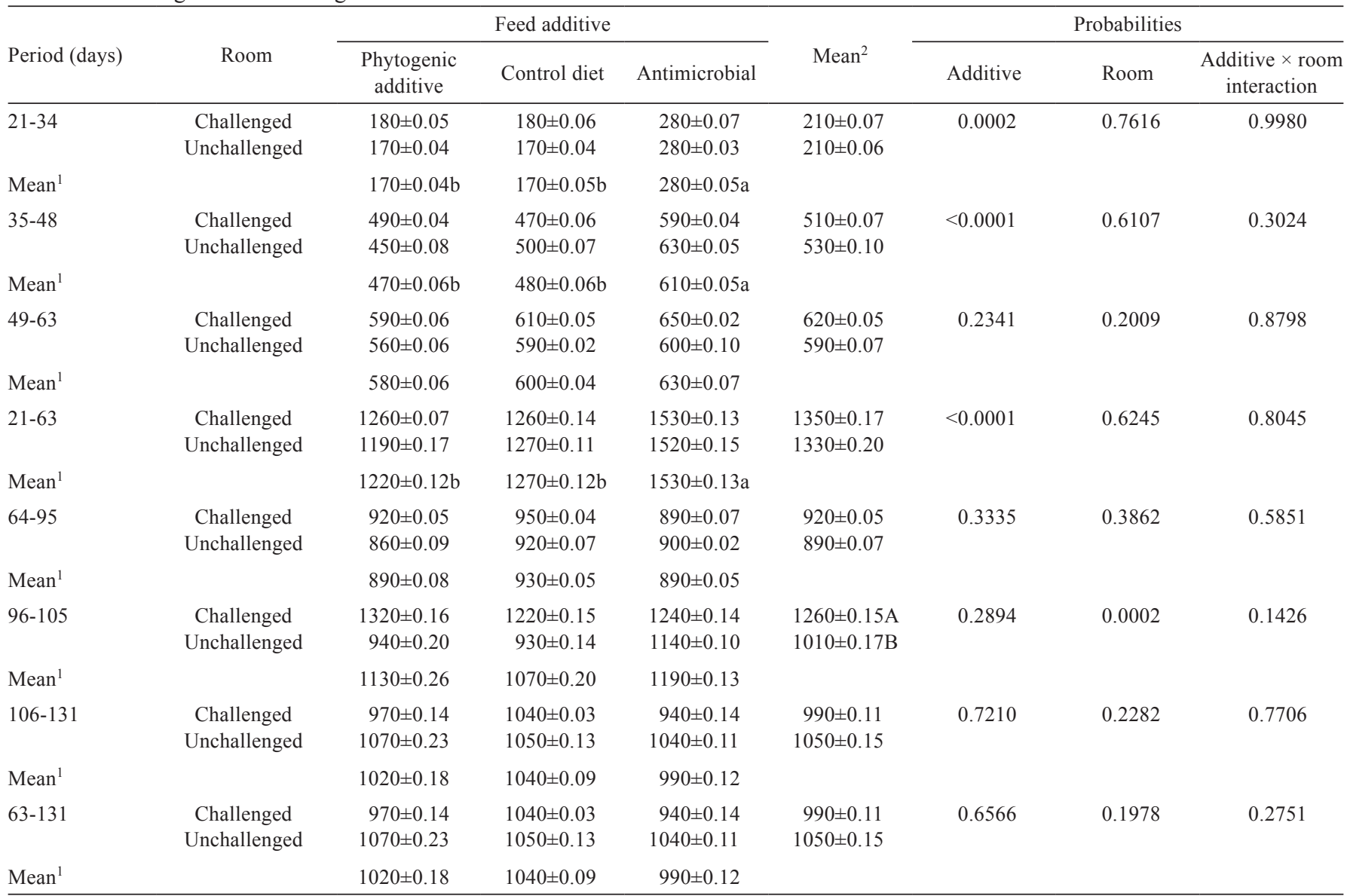

Means followed by different lowercase letters in the same row, or uppercase letters in the same column are different by Tukey's test ( $\mathrm{P}<0.05)$.

Mean ${ }^{1}$ : means of the different additives.

Mean ${ }^{2}$ : means of each room.

${ }^{3}$ Mean \pm standard deviation of the treatment. 


\section{Results and Discussion}

The parameters analyzed (BW, DWG, DFI, FC, FDD and lipid oxidation) did not show any interaction between the factors challenge and additive. Piglets in the antimicrobial agent treatment showed greater $(\mathrm{P}<0.05)$ body weight compared with the other treatments during the starter phase $(27.2 \pm 2.18 v s .22 .9 \pm 1.90$ and $23.6 \pm 1.78 \mathrm{~kg}$, for ATB $v s$. PHY and CTR, respectively) with no difference between control and phytogenic additives $(\mathrm{P}>0.05)$. After this phase, specifically at 96 and 106 days of age, the weight of the piglets in the phytogenic additives and control treatments, and in antimicrobial agent and control treatments were similar, with differences $(\mathrm{P}<0.05)$ between antimicrobial agent and phytogenic additives (56.8 vs. $52.5 \mathrm{~kg}$ and $68.7 \mathrm{vs} .63 .8 \mathrm{~kg}$ ). At 131 days of age, there was no difference $(\mathrm{P}>0.05)$ between the treatments. As for the challenge factor, there were differences between the animals kept in the challenged $(67.8 \mathrm{~kg})$ and unchallenged rooms $(64.1 \mathrm{~kg})$ only at 106 days of age $(\mathrm{P}<0.05)$.
Namkung et al. (2004) observed lighter weight in pigs that received herbal extracts, compared with animals that received antibiotics, and this fact was explained by the authors by the decrease in feed intake caused by the herbs. However, in the present study, this reduced intake was not observed. In addition to these authors, Utiyama et al. (2006) also observed greater live weight $(\mathrm{P}<0.05)$ in piglets that received antimicrobial compounds in the diet compared with those that were fed plant extracts and basic feed without growth promoters.

As for daily weight gain (DWG) and daily feed intake (DFI) until 48 days of age, the antimicrobial agent group was superior $(\mathrm{P}<0.05)$ to the other groups. From the 49th day on, there were no differences $(\mathrm{P}>0.05)$ between the treatments, a condition that was maintained until the 131st day of age (Tables 3 and 4). From 21 to 63 days of age, animals that received feed with antimicrobial agent presented greater DFI $(\mathrm{P}>0.05)$ compared with the other treatments. Similarities were detected between phytogenic additives and control for both parameters. Piglets in the

Table 4 - Daily feed intake (g/day) in piglets receiving feed with addition of phytogenic additive, antimicrobial, or the control diet kept in challenged or unchallenged rooms ${ }^{3}$

\begin{tabular}{|c|c|c|c|c|c|c|c|c|}
\hline \multirow[b]{2}{*}{ Period (days) } & \multirow[b]{2}{*}{ Room } & \multicolumn{3}{|c|}{ Feed additive } & \multirow[b]{2}{*}{ Mean $^{2}$} & \multicolumn{3}{|c|}{ Probabilities } \\
\hline & & $\begin{array}{l}\text { Phytogenic } \\
\text { additive }\end{array}$ & Control diet & Antimicrobial & & Additive & Room & $\begin{array}{c}\text { Additive } \times \text { room } \\
\text { interaction }\end{array}$ \\
\hline \multirow[t]{2}{*}{$21-34$} & Challenged & $300 \pm 0.04$ & $290 \pm 0.03$ & $360 \pm 0.05$ & $320 \pm 0.05$ & 0.0004 & 0.9276 & 0.5623 \\
\hline & Unchallenged & $280 \pm 0.06$ & $290 \pm 0.02$ & $390 \pm 0.04$ & $320 \pm 0.06$ & & & \\
\hline Mean $^{1}$ & & $290 \pm 0.05 b$ & $290 \pm 0.02 b$ & $380 \pm 0.05 \mathrm{a}$ & & & & \\
\hline \multirow[t]{2}{*}{$35-48$} & Challenged & $510 \pm 0.08$ & $520 \pm 0.10$ & $640 \pm 0.09$ & $560 \pm 0.10 \mathrm{~B}$ & 0.002 & 0.024 & 0.6632 \\
\hline & Unchallenged & $560 \pm 0.09$ & $600 \pm 0.10$ & $770 \pm 0.10$ & $640 \pm 0.13 \mathrm{~A}$ & & & \\
\hline Mean $^{1}$ & & $540 \pm 0.08 b$ & $560 \pm 0.10 b$ & $700 \pm 0.11 \mathrm{a}$ & & & & \\
\hline \multirow[t]{2}{*}{$49-63$} & Challenged & $1200 \pm 0.05$ & $1240 \pm 0.12$ & $1330 \pm 0.14$ & $1260 \pm 0.12$ & 0.076 & 0.5533 & 0.9107 \\
\hline & Unchallenged & $1130 \pm 0.20$ & $1220 \pm 0.12$ & $1320 \pm 0.19$ & $1220 \pm 0.18$ & & & \\
\hline Mean $^{1}$ & & $1170 \pm 0.14$ & $1230 \pm 0.12$ & $1330 \pm 0.16$ & & & & \\
\hline \multirow[t]{2}{*}{$21-63$} & Challenged & $670 \pm 0.03$ & $680 \pm 0.08$ & $780 \pm 0.09$ & $710 \pm 0.08$ & 0.007 & 0.6121 & 0.7676 \\
\hline & Unchallenged & $660 \pm 0.11$ & $700 \pm 0.08$ & $830 \pm 0.11$ & $730 \pm 0.12$ & & & \\
\hline Mean $^{1}$ & & $660 \pm 0.07 b$ & $690 \pm 0.08 b$ & $800 \pm 0.10 \mathrm{a}$ & & & & \\
\hline \multirow[t]{2}{*}{$64-95$} & Challenged & $2080 \pm 0.26$ & $2010 \pm 0.12$ & $2020 \pm 0.28$ & $2040 \pm 0.21$ & 0.9600 & 0.1772 & 0.7196 \\
\hline & Unchallenged & $1860 \pm 0.12$ & $1940 \pm 0.18$ & $1980 \pm 0.18$ & $1920 \pm 0.16$ & & & \\
\hline Mean $^{1}$ & & $1970 \pm 0.22$ & $1970 \pm 0.15$ & $2000 \pm 0.22$ & & & & \\
\hline \multirow[t]{2}{*}{$96-105$} & Challenged & $2780 \pm 0.06$ & $2870 \pm 0.15$ & $2940 \pm 0.25$ & $2870 \pm 0.17 \mathrm{~A}$ & 0.1121 & 0.0414 & 0.8826 \\
\hline & Unchallenged & $2580 \pm 0.18$ & $2760 \pm 0.14$ & $2790 \pm 0.24$ & $2710 \pm 0.20 \mathrm{~B}$ & & & \\
\hline Mean $^{1}$ & & $2670 \pm 0.16$ & $2820 \pm 0.15$ & $2860 \pm 0.24$ & & & & \\
\hline \multirow[t]{2}{*}{$106-131$} & Challenged & $3230 \pm 0.28$ & $3130 \pm 0.14$ & $3190 \pm 0.16$ & $3190 \pm 0.19 \mathrm{~A}$ & 0.8510 & 0.0497 & 0.3844 \\
\hline & Unchallenged & $2890 \pm 0.31$ & $3090 \pm 0.23$ & $3040 \pm 0.24$ & $3010 \pm 0.26 \mathrm{~B}$ & & & \\
\hline Mean $^{1}$ & & $3060 \pm 0.33$ & $3110 \pm 0.18$ & $3120 \pm 0.21$ & & & & \\
\hline \multirow[t]{2}{*}{$63-131$} & Challenged & $2520 \pm 0.17$ & $2510 \pm 0.07$ & $2590 \pm 0.14$ & $2540 \pm 0.12 \mathrm{~A}$ & 0.1898 & 0.0278 & 0.4547 \\
\hline & Unchallenged & $2340 \pm 0.08$ & $2470 \pm 0.11$ & $2490 \pm 0.14$ & $2430 \pm 0.12 B$ & & & \\
\hline Mean $^{1}$ & & $2420 \pm 0.15$ & $2490 \pm 0.09$ & $2540 \pm 0.14$ & & & & \\
\hline
\end{tabular}

Means followed by different lowercase letters in the same row, or uppercase letters in the same column are different by Tukey's test ( $\mathrm{P}<0.05$ ).

Mean ${ }^{1}$ : means of the different additives.

Mean ${ }^{2}$ : means of each room.

${ }^{3}$ Mean \pm standard deviation of the treatment. 
challenged room showed greater DWG $(\mathrm{P}<0.05)$ compared with those in the unchallenged room from 96 to 105 days. As for DFI in the period between 35 and 48 days of age, animals in the unchallenged room showed greater intake $(\mathrm{P}<0.05)$ when compared with those in the challenged room. These results are similar to those reported by Balaji et al. (2000), who observed a decrease in daily weight gain for 2 weeks and reduced intake for 120 hours after inoculation with Salmonella Typhimurium, possibly due to inflammatory changes linked to stress. Fraser et al. (2007), on the other hand, did not observe any influence from the inoculation of Salmonella Typhimurium on the piglet performance.

After 96 days of age, DFI started to be greater $(\mathrm{P}<0.05)$ in challenged animals, suggesting a compensatory effect. This kind of response was also observed by Turner et al. (2002), who reported that after 14 days of experimental inoculation with Salmonella Typhimurium, the performance of the challenged piglets was better than that of unchallenged ones. These authors also suggested a compensatory gain.
From 21 to 34 days, animals that received antimicrobial agent presented lower FC $(\mathrm{P}<0.05)$ compared with the control group, but these results did not differ from those observed for phytogenic additives (Table 5).

Animals challenged with Salmonella Typhimurium presented, from 35 to 48 days of age, lower FC $(\mathrm{P}<0.05)$ compared with animals in the unchallenged room. The feed conversion for animals in the challenged room was lower $(\mathrm{P}<0.05)$ from 35 to 48 days and from 96 to 105 days of age.

As for the frequency of diarrhea, before the inoculation of Salmonella Typhimurium, animals that were fed the antimicrobial agent showed lower $(\mathrm{P}<0.05)$ frequency compared with those that were fed phytogenic additives and control (Figure 1). After the challenge, from 35 to 48 days of age, animals of the antimicrobial agent treatment showed lower FDD (29.3\% of the days). Similar results were obtained by Oetting (2005), from 21 to 56 days of age, a period when the frequency of days with diarrhea

Table 5 - Feed conversion in piglets receiving feed with addition of phytogenic additive, antimicrobial, or the control diet, kept in challenged or unchallenged rooms ${ }^{3}$

\begin{tabular}{|c|c|c|c|c|c|c|c|c|}
\hline \multirow[b]{2}{*}{ Period (days) } & \multirow[b]{2}{*}{ Room } & \multicolumn{3}{|c|}{ Feed additive } & \multirow[b]{2}{*}{ Mean $^{2}$} & \multicolumn{3}{|c|}{ Probabilities } \\
\hline & & $\begin{array}{l}\text { Phytogenic } \\
\text { additive }\end{array}$ & Control diet & Antimicrobial & & Additive & Room & $\begin{array}{c}\text { Additive } \times \text { room } \\
\text { interaction }\end{array}$ \\
\hline \multirow[t]{2}{*}{$21-34$} & Challenged & $1.57 \pm 0.14$ & $1.77 \pm 0.47$ & $1.33 \pm 0.27$ & $1.55 \pm 0.36$ & 0.02 & 0.703 & 0.8943 \\
\hline & Unchallenged & $1.67 \pm 0.23$ & $1.74 \pm 0.39$ & $1.39 \pm 0.06$ & $1.60 \pm 0.29$ & & & \\
\hline Mean $^{1}$ & & $1.62 \pm 0.19 \mathrm{ab}$ & $1.75 \pm 0.41 \mathrm{a}$ & $1.35 \pm 0.19 b$ & & & & \\
\hline \multirow[t]{2}{*}{$35-48$} & Challenged & $1.05 \pm 0.20$ & $1.10 \pm 0.11$ & $1.07 \pm 0.09$ & $1.07 \pm 0.13 \mathrm{~B}$ & 0.9246 & 0.003 & 0.5916 \\
\hline & Unchallenged & $1.26 \pm 0.09$ & $1.19 \pm 0.05$ & $1.20 \pm 0.10$ & $1.22 \pm 0.08 \mathrm{~A}$ & & & \\
\hline Mean $^{1}$ & & $1.16 \pm 0.18$ & $1.14 \pm 0.09$ & $1.13 \pm 125$ & & & & \\
\hline \multirow[t]{2}{*}{$49-63$} & Challenged & $2.05 \pm 0.24$ & $2.01 \pm 0.15$ & $2.04 \pm 0.15$ & $2.03 \pm 0.17$ & 0.5165 & 0.5669 & 0.5113 \\
\hline & Unchallenged & $1.99 \pm 0.19$ & $2.04 \pm 0.16$ & $2.21 \pm 0.33$ & $2.08 \pm 0.24$ & & & \\
\hline Mean $^{1}$ & & $2.02 \pm 0.21$ & $2.03 \pm 0.15$ & $2.12 \pm 0.26$ & & & & \\
\hline \multirow[t]{2}{*}{$21-63$} & Challenged & $1.61 \pm 0.11$ & $1.62 \pm 0.09$ & $1.52 \pm 0.07$ & $1.58 \pm 0.10$ & 0.2331 & 0.08 & 0.6801 \\
\hline & Unchallenged & $1.66 \pm 0.06$ & $1.65 \pm 0.05$ & $1.62 \pm 0.12$ & $1.64 \pm 0.08$ & & & \\
\hline Mean $^{1}$ & & $1.63 \pm 0.09$ & $1.64 \pm 0.07$ & $1.57 \pm 0.10$ & & & & \\
\hline \multirow[t]{2}{*}{$63-95$} & Challenged & $2.25 \pm 0.27$ & $2.12 \pm 0.12$ & $2.28 \pm 0.25$ & $2.21 \pm 0.22$ & 0.6447 & 0.3373 & 0.4327 \\
\hline & Unchallenged & $2.17 \pm 0.12$ & $2.09 \pm 0.11$ & $2.19 \pm 0.18$ & $2.15 \pm 0.14$ & & & \\
\hline Mean $^{1}$ & & $2.21 \pm 0.20$ & $2.11 \pm 0.11$ & $2.23 \pm 0.21$ & & & & \\
\hline \multirow[t]{2}{*}{$96-105$} & Challenged & $2.22 \pm 0.23$ & $2.38 \pm 0.33$ & $2.40 \pm 0.36$ & $2.33 \pm 0.30 \mathrm{~B}$ & 0.121 & 0.0137 & 0.2534 \\
\hline & Unchallenged & $2.54 \pm 0.37$ & $3.00 \pm 0.49$ & $2.44 \pm 0.19$ & $2.67 \pm 0.43 \mathrm{~A}$ & & & \\
\hline Mean $^{1}$ & & $2.36 \pm 0.33$ & $2.69 \pm 0.51$ & $2.42 \pm 0.27$ & & & & \\
\hline \multirow[t]{2}{*}{$106-131$} & Challenged & $3.34 \pm 0.28$ & $3.01 \pm 0.22$ & $3.36 \pm 0.46$ & $3.23 \pm 0.34$ & 0.7904 & 0.1001 & 0.1923 \\
\hline & Unchallenged & $2.83 \pm 0.78$ & $2.99 \pm 0.62$ & $2.94 \pm 0.38$ & $2.92 \pm 0.57$ & & & \\
\hline Mean $^{1}$ & & $3.08 \pm 0.61$ & $3.00 \pm 0.43$ & $3.13 \pm 0.45$ & & & & \\
\hline \multirow[t]{2}{*}{$63-131$} & Challenged & $2.55 \pm 0.14$ & $2.50 \pm 0.10$ & $2.67 \pm 0.17$ & $2.56 \pm 0.15$ & 0.9067 & 0.7904 & 0.1923 \\
\hline & Unchallenged & $2.57 \pm 0.31$ & $2.67 \pm 0.15$ & $2.52 \pm 0.12$ & $2.59 \pm 0.20$ & & & \\
\hline Mean $^{1}$ & & $2.56 \pm 0.23$ & $2.59 \pm 0.15$ & $2.59 \pm 0.16$ & & & & \\
\hline
\end{tabular}

Means followed by different lowercase letters in the same row, or uppercase letters in the same column are different by Tukey's test ( $<<0.05$ ).

Mean ${ }^{1}$ : means of the different additives.

Mean ${ }^{2}$ : means of each room.

${ }^{3}$ Mean \pm standard deviation of the treatment. 
was lower for piglets that received antimicrobials in the feed compared with those that were fed plant extract or no additive.

Animals in the phytogenic additive treatment showed lower FDD $(81.4 \% ; \mathrm{P}<0.05)$ compared with those in the control group ( $97.8 \%$, Figure 1$)$.

Between the two rooms, animals in the challenged room showed greater FDD $(\mathrm{P}<0.05)$ between 21 and 34 days of age, with no differences in the other periods $(\mathrm{P}<0.05$; Figure 2).

Lipid oxidation of the carcass was evaluated by means of the thiobarbituric acid reactive substances assay (TBARS) with the release of malondialdehyde by intramuscular fat.

Malondialdehyde indicates the degree of muscle fat oxidation. The greater the amount of malondialdehyde per $\mathrm{kg}$ of muscle, the lower the resistance of the meat to oxidation. Oxidative rancidity, or lipid peroxidation, is the main cause of loss of quality in feedstuffs or feeds, affecting their taste, flavor, color, and texture, besides seriously decreasing the nutritional value (Scott et al., 1982).

The mean concentration of malondialdehyde in the muscle tissue was not different $(\mathrm{P}>0.05)$ between the treatments, indicating that none of them significantly decreased the degree of oxidation of intramuscular fat (Figure 3).

The mean melondialdehyde concentration in the phytogenic additive and antimicrobial agent treatments was numerically similar, and both were numerically superior to the concentration in the control group. Therefore, this result is different from that reported by Botsoglou et al. (2004), who observed a decrease in the oxidation of intramuscular fat in pigs that received medicinal herbs added to the feed. Besides, Janz et al. (2007) reported a tendency for greater oxidative stability in pigs fed oregano essential oils, compared with the control group.

The plants Origanum vulgare and Rosmarinus officinalis are the most commonly studied in relation to antioxidant activity in meat, and several authors observed an improvement in these parameters in broilers (Botsoglou et al., 2002; Basmacioglou et al., 2004), turkeys (Govaris et al., 2007) and rabbits (Botsoglou et al., 2004) after supplementation of the diet with these herbs.

Moreno et al. (2006) reported the antioxidant activity of compounds from medicinal herbs administered orally to animals. These compounds, especially polyphenols, may be absorbed by the blood stream during digestion and accumulate in the meat, offering greater oxidative stability and increasing the shelf life of the product.

According to Olivo \& Shimokomaki (2002), meat products with TBARS indexes lower than $1 \mathrm{mg} / \mathrm{kg}$ usually do not have residual rancid taste or flavor characteristic of

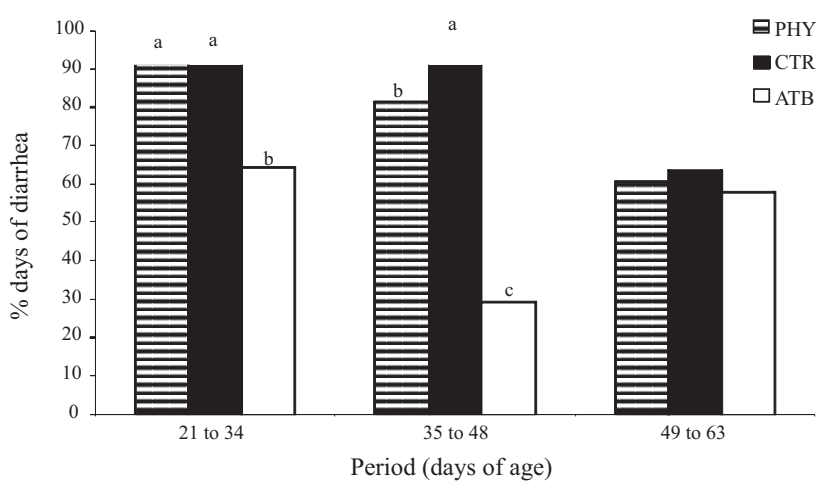

Means of the same period with different lowercase letters are statistically different by Tukey's test at a $5 \%$ significance level.

Figure 1 - Frequency of days with diarrhea in piglets receiving feed with phytogenic additive (PHY), antimicrobial (ATB), or the control diet (CTR) from 21 to 34,35 to 48 and 49 to 63 days of age.

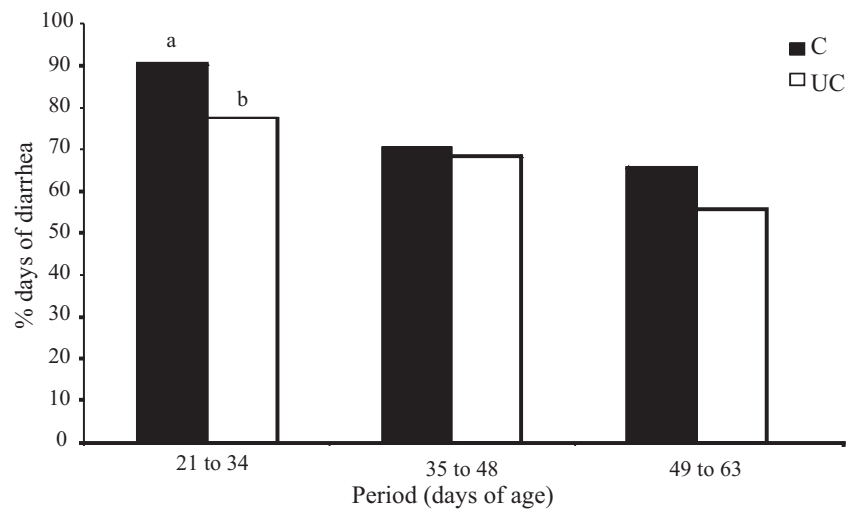

Means of the same period with different lowercase letters are statistically different by Tukey's test, at a 5\% significance level.

Figure 2 - Frequency of days with diarrhea in piglets in the challenged (C) and unchallenged (UC) rooms from 21 to 34,35 to 48 and 49 to 63 days of age.

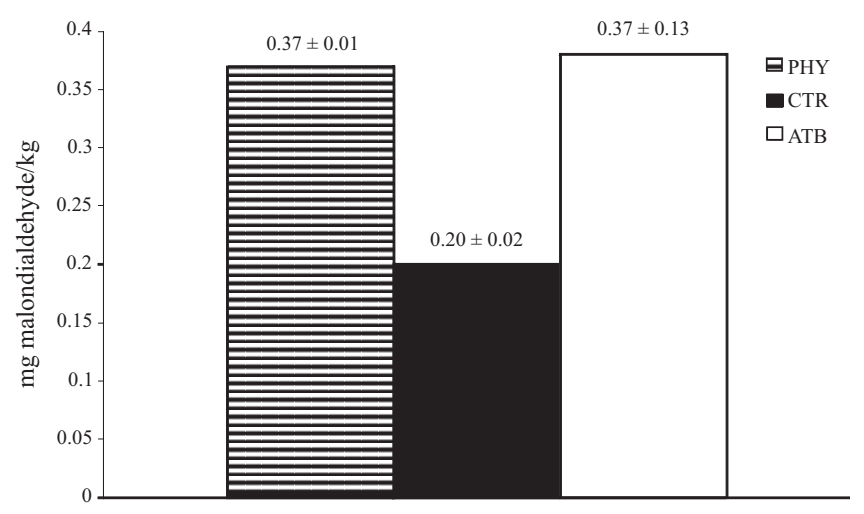

Figure 3 - Means \pm standard deviation of the malondialdehyde $(\mathrm{mg} / \mathrm{kg}$ of muscle tissue) in piglets receiving the phytogenic additive (PHY), antimicrobial agent (ATB), or the control diet (CTR). 
lipid oxidation. Therefore, the TBARS results of the present study indicate that there was no sensory change with any of the additives used (phytogenic feed additives, control and antimicrobial agent).

\section{Conclusions}

Antimicrobials showed better effects on animal performance and frequency of diarrhea in the starter phase. In the growth and finishing phases, feed supplementation with antibiotics did not show different results from the use of phytogenic additive or the control diet. Lipid oxidation was not influenced by any of the treatments tested.

\section{Acknowledgements}

To Fundação de Amparo à Pesquisa do Estado de São Pesquisa (FAPESP) for the financial support for this project and for the Master's degree grant.

\section{References}

ALEXOPOULOS, C.; GEORGOULAKIS, I.E.; TZIVARA, A. et al. Field evaluation of the effect of a probiotic-containing Bacillus licheniformis and Bacillus subtilis spores on the health status, performance, and carcass quality of grower and finisher pigs. Journal Veterinary Medicine, v.51, p.306-312, 2004.

BALAJI, R.; WRIGHT, K.J.; HILL, C.M. et al. Acute phase responses of pigs challenged orally with Salmonella typhimurium. Journal of Animal Science, v.78, p.1885-1891, 2000.

BANZATTO, D.A.; KRONKA, S.N. Experimentação agrícola. Jaboticabal: Funep, 1989. 247p.

BASMACIOGLOU, H; TOKUSOGLOU, Ö.; ERGÜL, M. The effect of orégano and rosemary essential oils or alpha-tocopheryl acetate on performance and lipid oxidation of meat enriched with n-3 PUFA's in broilers. South African Journal of Animal Science, v.34, n.3, p.197-210, 2004.

BOTSOGLOU,N.A.;FLOROU-PANERI,P.;CHRISTAKI,E.etal.Effect of dietary oregano essential oil on performance of chickens and on iron-inducedlipidoxidation of breast, thigh andabdominal fattissues. Britsh Poultry Science, v.43, n.2, p.223-230, 2002.

BOTSOGLOU, N.A.; FLOROU-PANERI, P.; CHRISTAKI, E. et al. Performance of rabbits and oxidative stability of muscle tissues as affected by dietary supplementation with oregano essential oil. Archives of Animal Nutrition, v.58, n.3, p.209-218, 2004.

DEBERSAC P.; HEYDEL, J.M.; AMIOT, M.J. Induction of cytochrome $\mathrm{P} 450$ and/or detoxication enzymes by various extracts of rosemary: description of specific patterns. Food and Chemical Toxicology, v.39, n.9, p.907-918, 2001.

DUARTE, M.C.; FIGUEIRA, G.M.; SARTORATTO, A. et al. Anti-Candida activity of Brazilian medicinal plants. Journal of Ethnopharmacology, v.97, n.2, p.305-311, 2005.
FRASER, J.N.; DAVIS, B.L.; SKJOLAAS, K.A. et al. Effects of feeding Salmonella enterica serovar Typhimurium or serovar Choleraesuis on growth performance and circulating insulin-like growth factor-I, tumor necrosis factor- $\alpha$, and interleukin- $1 \beta$ in weaned pigs. Journal of Animal Science, v.85, p.1161-1167, 2007.

GOVARIS, A.; FLOROU-PANERI, P.; BOTSOGLOU, E. et al. The inhibitory potential of feed supplementation with rosemary and/or $\alpha$-tocopheryl acetate on microbial growth and lipid oxidation of turkey breast during refrigerated storage. LWT-Food Science and Technology, v.40, p.331-337, 2007.

JANZ, J.A.M.; MOREL, P.C.H.; WILKINSONPURCHAS, B.H.P et al. Preliminary investigation of the effects of low-level dietary inclusion of fragrant essential oils and oleoresins on pig performance and pork quality. Meat Science, v.75, p.350-355, 2007.

MARTINS, S.M.M.K., ALMEIDA, E.; MICHELONE, P.C. et al. Adição de um composto de ervas naturais na dieta de suínos na fase de crescimento e terminação. In: CONGRESSO BRASILEIRO DE VETERINÁRIOS ESPECIALISTAS EM SUÍNOS, 12., 2005, Fortaleza. Anais... Fortaleza, 2005. v.2. p.398-399.

MAZEL, D.; DAVIES, J. Antibiotic resistance in microbes. Cellular and Molecular Life Sciences, v.56, p.742-754, 1999.

MORENO, S.; SCHEYER, T.; ROMANO, C.S. et al. Antioxidant and antimicrobial activities of rosemary extracts linked to their polyphenol composition. Free Radical Research, v.40, n.2, p.223-231, 2006.

NAMKUNG, H.; LI, M.; GONG, J. et al. Impact of feeding blends of organic acids and herbal extracts on growth performance, gut microbiota and digestive function in newly weaned pigs. Canadian Journal of Animal Science, v.84, p.697-704, 2004.

NATIONAL RESEARCH COUNCIL - NRC. Nutrient requirements of swine. 10. rev. ed. Washington, D.C.: Natl. Acad. Press, 1998. $189 \mathrm{p}$

OETTING, L.L. Extratos vegetais como promotores do crescimento de leitões recém-desmamados. 2005. 66f. Tese (Doutorado em Ciência Animal e Pastagens) - Escola Superior de Agricultura "Luiz de Queiroz"/Universidade de São Paulo, Piracicaba.

OLIVO, R.; SHIMOKOMAKI, M. Carnes: no caminho da pesquisa. 2.ed. Cacoal do Sul: Imprint, 2002. 155p.

SCOTT, M.L.; NESHEIN, M.C.; YOUNG, R.J. Nutrition of the chicken. 3.ed. Ithaca: M.L. SCOTT \& Associates, 1982. 562p.

SPELMAN, K.; BURNS, J.J.; NICHOLS, D. et al. Modulation of cytokine expression by traditional medicines: a review of herbal immunomodulators. Alternative Medicine Review, v.11, n.2, 2006.

TURNER, J.L.; DRITZ, S.S.; HIGGINS, J.J. et al. Effects of Ascophyllum nodosum extract on growth performance and immune function of young pigs challenged with Salmonella typhimurium. Journal of Animal Science, v.80, p.1947-1953, 2002.

UTIYAMA, C.E.; OETTING, L.L.; GIANI, P.A. et al. Efeitos de antimicrobianos, prebióticos, probióticos e extratos vegetais sobre a microbiota intestinal, a freqüência de diarréia e o desempenho de leitões recém-desmamados. Revista Brasileira de Zootecnia, v.35, n.6, p.2359-2367, 2006.

VYNCKE, B.W. Direct determination of the thiobarbituric acid value in trichloracetic acid extracts of fish as a measure of oxidative rancidity. Fette Seifen Anstrichmittel, v.72, n. 12, p.1084-1087, 1970.

ZANI, J.L.; DA CRUZ, F.W.; DOS SANTOS, A.F. et al. Effect of probiotic cenbiot on the control of diarrhoea and feed efficiency in pigs. Journal of Applied Microbiology, v.84, p.68-71, 1998. 